\title{
In vitro Acaricidal Activity of Ocimum gratissimum Essential Oil on Rhipicephalus sanguineus, Amblyomma sculptum and Rhipicephalus microplus Larvae
}

\author{
Ferreira, T. P.; Cid, Y. P.; Alves, M. C. C.; Santos, G. C. M.; Avelar, B. R.; \\ Freitas, J. P.; Ożarowski, M.; de Souza, M. A. A.; Chaves, D. S. A.*
}

Rev. Virtual Quim., 2019, 11 (5), 1604-1613. Data de publicação na Web: 29 de outubro de 2019

http://rvq.sbq.org.br

\begin{abstract}
Atividade Acaricida in vitro do Óleo Essencial de Ocimum gratissimum Sobre Larvas de Rhipicephalus sanguineus, Amblyomma sculptum e Rhipicephalus microplus
\end{abstract}

\begin{abstract}
Resumo: O uso de óleos essenciais para o controle de ectoparasitos de interesse veterinário pode ser uma excelente alternativa aos compostos sintéticos comercializados como forma de reduzir os impactos negativos na saúde humana e no meio ambiente. A incidência de diferentes espécies de carrapatos em diferentes locais é resultado das características ambientais do território nacional. Entre as espécies de interesse veterinário estão Amblyomma sculptum, Rhipicephalus microplus e Rhipicephalus sanguineus. Óleos essenciais (OEs) de Ocimum sp exibem uma gama de atividades biológicas, como inseticida, acaricida e repelência de insetos. 0 objetivo deste estudo foi avaliar a atividade in vitro e estabelecer a $\mathrm{CL}_{50}$ do $\mathrm{OE}$ de Ocimum gratissimum contra larvas de $A$. sculptum, $R$. microplus e $R$. sanguineus, a fim de explorar o potencial de uso desse OE no controle de carrapatos. Os resultados do bioensaio mostraram que $\mathrm{O} \mathrm{OE}$ de $O$. gratissimum apresentou grande atividade acaricida contra todas as larvas testadas na faixa de concentração avaliada. A atividade larvicida foi mais pronunciada para $R$. microplus $\left(\mathrm{CL}_{50}=2,0 \mathrm{mg} \mathrm{mL}^{-1}\right)$ quando comparada a $A$. sculptum $\left(\mathrm{CL}_{50}=5,5 \mathrm{mg} \cdot \mathrm{mL}^{-1}\right)$ e $R$. sanguineus $\left(\mathrm{CL}_{50}=6,2 \mathrm{mg} \cdot \mathrm{mL}^{-1}\right)$. Estes resultados são promissores para o desenvolvimento de produtos fitoterápicos para obtenção de um método alternativo de controle de larvas de carrapatos, minimizando o uso de produtos sintéticos.
\end{abstract}

Palavras-chave: Eugenol; eucaliptol; CG; carrapato; acaricida.

\begin{abstract}
The essential oil use for veterinary ectoparasites control may be an excellent alternative to synthetic compounds marketed, as a way to reduce negative impacts on human health, and the environment. The incidence of different tick species in different locations is a result of the environmental characteristics of the national territory. Among the veterinary interest species are Amblyomma sculptum, Rhipicephalus microplus and Rhipicephalus sanguineus. Ocimum sp essential oils (EOs) exhibit a range of biological activities such as insecticide, acaricide and insect repellency. The aim of this study was to evaluate in vitro activity and establish the $\mathrm{LC}_{50}$ of Ocimum gratissimum EO against $A$. sculptum, $R$. microplus and $R$. sanguineus larvae in order to explore the potential use of this essential oil in tick control. The bioassay results showed that $O$. gratissimum essential oil exhibited great acaricidal activity against all larvae tick tested in the evaluated concentration range. Larvicidal activity was more pronounced for $R$. microplus $\left(\mathrm{LC}_{50}=\right.$ $2.0 \mathrm{mg} \cdot \mathrm{mL}^{-1}$ ) when compared to A. sculptum $\left(\mathrm{LC}_{50}=5.5 \mathrm{mg} \cdot \mathrm{mL}^{-1}\right)$ and $R$. sanguineus $\left(\mathrm{LC}_{50}=6.2 \mathrm{mg} \cdot \mathrm{mL}^{-1}\right)$. These results are promising for the development of herbal products to obtain an alternative method of controlling tick larvae while minimizing the use of synthetic products.
\end{abstract}

Keywords: Eugenol; eucalyptol; GC; tick; acaricidal.

\footnotetext{
* Universidade Federal Rural do Rio de Janeiro, Instituto de Ciências Biológicas e da Saúde, Departamento de Ciências Farmacêuticas, CEP 23897-000, Seropédica-RJ, Brazil.

Mgnosy.ufrrj@gmail.com

DOI: $\underline{10.21577 / 1984-6835.20190112}$
} 


\section{In vitro Acaricidal Activity of Ocimum gratissimum Essential Oil on Rhipicephalus sanguineus, Amblyomma sculptum and Rhipicephalus microplus Larvae}

Thais P. Ferreira, ${ }^{\text {a }}$ Yara P. Cid, ${ }^{\mathrm{b}}$ Melina A. Cardilo, ${ }^{\mathrm{c}}$ Gabriela C. M. dos

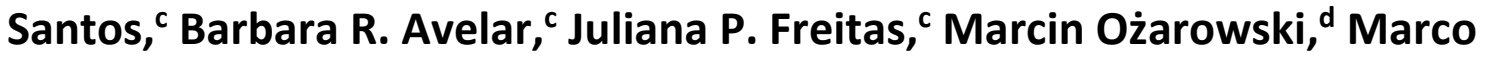
A. A. de Souza, ${ }^{e}$ Douglas S. A. Chaves ${ }^{\mathrm{b}, *}$

a Universidade Federal Rural do Rio de Janeiro, Programa de Pós-Graduação em Química, Instituto de Química, BR 465, km 7, CEP 23897-000, Seropédica-RJ, Brazil.

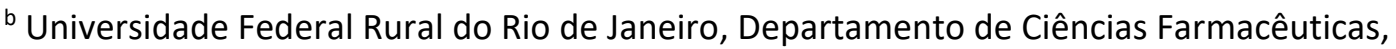
Instituto de Ciências Biológicas e da Saúde, BR 465, km 7, CEP 23897-000, Seropédica-RJ, Brazil.

c Universidade Federal Rural do Rio de Janeiro, Programa de Pós-Graduação em Ciências Veterinárias, Instituto de Veterinária, BR 465, km 7, CEP 23897-000, Seropédica-RJ, Brazil.

${ }^{d}$ Department of Biotechnology, Institute of Natural Fibres and Medicinal Plants, Wojska Polskiego 71b, 60-630 Poznań, Poland.

e Universidade Federal Rural do Rio de Janeiro, Departamento de Bioquímica, Instituto de Química, BR 465, km 7, CEP 23897-000, Seropédica-RJ, Brazil.

*gnosy.ufrri@gmail.com

Recebido em 30 de setembro de 2019. Aceito para publicação em 30 de setembro de 2019

1. Introduction

2. Material and Methods

2.1. Plant material

2.2. Extraction, content and chemical characterization of the essential oil

2.3. In vitro larvicidal assay

2.4. Statistical analysis

3. Results and Discussion

3.1. Content and chemical characterization of the essential oil

3.2. Larvicidal activity

3.3. LC $_{50}$ establishment

4. Conclusion 


\section{Introduction}

Essential oils are natural products obtained from plants, mainly by hydrodistillation or steam distillation, principally containing monoterpenes, sesquiterpenes and phenylpropanoids. ${ }^{1}$ Essential oils' chemical complexity gives them a broad spectrum of biological action, so they have been investigated for the control of pests and diseases that affect crops and human health. ${ }^{2,3}$ In this context, different studies have demonstrated essential oils' toxic effect against ectoparasites of veterinary interest. ${ }^{4,5}$ Indeed, the use of essential oils for veterinary ectoparasite control can be an excellent alternative to the use of synthetic compounds, by reducing negative impacts on human health and the environment, ${ }^{6}$ besides minimizing the development of tick resistance. $^{7}$

The wide geographic dispersion of different tick species is a result of the environmental characteristics of the endemic regions. ${ }^{8}$ Among the species of veterinary interest are Amblyomma sculptum, Rhipicephalus microplus and Rhipicephalus sanguineus. Amblyomma sculptum, popularly called the "star tick", has low parasitic specificity, so many species of animals can serve as hosts, including humans. ${ }^{8,9}$ It is an important public health problem since it is main transmitter of the bacterium Rickettsia rickettsii, the etiological agent of Brazilian macular fever. ${ }^{10}$ Rhipicephalus microplus is the main cattle tick and contributes to the spread of various diseases in livestock. ${ }^{11}$ It is estimated that this tick causes losses of up to US\$ 3.2 billion in the Brazilian livestock sector, considering treatment costs and reduced productivity. ${ }^{12,13}$ Rhipicephalus sanguineus has high prevalence in dogs, but human infestations have been reported ${ }^{13}$, and it can transmit pathogens such as Babesia canis and Ehrlichia canis. ${ }^{14}$

The use of parasiticides is the main strategy for control of these ectoparasites. The immature stages (eggs and larvae) of ticks are more sensitive, so reducing them leads to a decrease in the number of adults. ${ }^{15}$ The search for sustainable alternatives to reduce the economic and environmental impact includes investigation of essential oils (EOs) for the control of parasites. ${ }^{16}$

The Ocimum genus, belonging to the Lamiaceae family, ${ }^{17,18}$ exhibits a high degree of polymorphism, so a large number of subspecies exist (over 150) that produce EOs of varying chemical composition, offering variable levels of potential activity. ${ }^{16}$ In particular, Ocimum $s p$ EOs have a range of biological activities, such as insecticidal, acaricidal, insect repellency, antimicrobial, antioxidant and anti-inflammatory. ${ }^{17} \mathrm{O}$. gratissimum occurs spontaneously throughout Brazil, ${ }^{18}$ and three chemotypes are known: thymol, geraniol and eugenol (the most common), which has an essential oil rich in two compound (eugenol and eucalyptol. ${ }^{19}$

To ensure the efficacy and safety of using EOs to control ticks, it is first necessary to determine effective concentrations. In vitro activity evaluation and $\mathrm{LC}_{50}$ establishment are important tools at this stage. Therefore, the aim of this study was to evaluate the in vitro activity and establish the $\mathrm{LC}_{50}$ of Ocimum gratissimum EO against $A$. sculptum, $R$. microplus and $R$. sanguineus larvae in order to explore the potential use of this essential oil for tick control.

\section{Material and Methods}

\subsection{Plant material}

Leaves of Ocimum gratissimum L. (Clove basil) were collected at the Botanical garden of the Universidade Federal Rural do Rio de Janeiro - 2018 (GPS 22 $31^{\prime} 36.23$ S; $44^{\circ} 04^{\prime} 31.62 \mathrm{~W}$ ), dried in an over chamber at $37{ }^{\circ} \mathrm{C}$ during $72 \mathrm{~h}$ and manually pulverized. The specimen voucher was deposited in the Herbarium of the Institute of Botany (UFRRJ, Brazil) number RBR 36382. 


\subsection{Extraction, content and chemical characterization of the essential oil}

Essential oil from dried leaves was obtained by hydrodistillation in a Clevenger apparatus for $3 \mathrm{~h}$, then, dried with anhydrous $\mathrm{Na}_{2} \mathrm{SO}_{4}$. GC analysis was carried out on a Hewlett-Packard 5890 II (Palo Alto, USA) apparatus equipped with flame ionization detection (FID) and a split/splitless injector. Injected volume was $1 \mu \mathrm{L}$ on a 1:20 split ratio. Helium was used as the carrier gas at a flow rate of $1.0 \mathrm{ml} \mathrm{min}$. Substances were separated into a fused silica capillary column HP-5 (30 m $\times 0.25 \mathrm{~mm}$ i.d., $0.25 \mu \mathrm{m}$, Agilent J $\& W)$. The column temperature was programmed as follows: $60{ }^{\circ} \mathrm{C}$ for $2 \mathrm{~min}$ followed by heating at $5{ }^{\circ} \mathrm{C} \mathrm{min}-1$ to $110{ }^{\circ} \mathrm{C}$, followed by heating at $3{ }^{\circ} \mathrm{C} \mathrm{min}{ }^{-1}$ to $150^{\circ} \mathrm{C}$ and finally followed by heating at $15^{\circ} \mathrm{C} \mathrm{min}-1$ until $290{ }^{\circ} \mathrm{C}$ and holding constant for $15 \mathrm{~min}$. The injector temperature was $220{ }^{\circ} \mathrm{C}$ and the detector temperature was $290{ }^{\circ} \mathrm{C}$ as reported by Adams (2007). ${ }^{16}$ Percentage of essential oil compounds were calculated from the relative area of each peak analyzed by GC-FID. Essential oil was also analyzed on a GC-MS QP2010 Plus (Shimadzu, JPN). Carrier gas flow, capillary column and temperature conditions for GC/MS analysis were the same as those described for GC-FID and reported by Adams $(2007)^{20}$. The temperature of the injector was $220{ }^{\circ} \mathrm{C}$ and the temperature of the interface was $250{ }^{\circ} \mathrm{C}$. Mass spectrometer operating conditions were ionization voltage at $70 \mathrm{eV}$ and mass range $40-400 \mathrm{~m} / \mathrm{z}$ and $0.5 \mathrm{scan} / \mathrm{s}$. The compounds retention index were calculated based on co-injection of samples with a $\mathrm{C}_{8}-\mathrm{C}_{20}$ hydrocarbon mixture as reported by van Den Dool and Kratz (1963) ${ }^{21}$. Constituents were identified by comparison of their mass spectra with the NIST library (2008) and with those reported by Adams (2007). ${ }^{20}$

\subsection{In vitro larvicidal assay}

Bioassays were performed using Larval Immersion Test (LIT) method (Shaw 1966) ${ }^{22}$ adapted for Leite $(1988)^{23}$ and Chagas et al, 2002. ${ }^{24}$ Stock solutions at a concentration of $200 \mathrm{mg} \cdot \mathrm{mL}^{-1}$ of essential oil from Ocimum gratissimum was prepared using a mixture of acetone (Synth, code: 219385), distilled water and Tween-80 (Vetec, code: 0803511) as diluent, an innocuous solvent able to dissolve the essential oil constituents, which was also used as negative control. Fipronil at 400 $\mu \mathrm{g} \cdot \mathrm{mL}^{-1}$ was used as positive control to ensure viability of the colony. Serial dilutions (1:2) were performed from stock solutions allowing for ten solutions in a concentration range varying from 40 to $0.0781 \mathrm{mg} \cdot \mathrm{mL}^{-1}$.

For each concentration approximately 100 non-fed 21 days old larvae of each tick ( $A$. sculptum, $R$. sanguineus and $R$. microplus) were deposited on a $2 \mathrm{~cm} \times 2 \mathrm{~cm}$ filter paper sandwich, which was impregnated with $0.5 \mathrm{~mL}$ of the solution under test. The filter paper sandwich was wrapped in a filter paper envelope $(6 \mathrm{~cm} \times 6 \mathrm{~cm})$ properly sealed with binder clips. The envelopes were kept in a climatized chamber at $27 \pm 1{ }^{\circ} \mathrm{C}$ and relative humidity of $80 \pm 10 \%$ for $24 \mathrm{~h}$ for subsequent mortality assessment. The evaluation criterion used was motility, any larva that presented minimal movement was considered alive. The mean number of live larvae per concentration was evaluated in periods of mainly 24 hours with the help of a stereoscopic microscope. The tests were performed in duplicates for each concentration. Mortality was calculated according to the following formula: Mortality (\%): dead larvae x $100 /$ total larvae

The experiments followed the standards established by the Ethics Committee for Animal Use of the Institute of Veterinary (CEUA). Tick larvae of Amblyomma sculptum (CEUA/IV $\mathrm{n}^{\circ}$ 7699190418), Rhipicephalus microplus (CEUA/IV $\mathrm{n}^{\circ}$ 4667181218) and Rhipicephalus sanguineus (CEUA/IV $\mathrm{n}^{\circ}$ 092/14) used in the experiment were obtained from colonies maintained in the 
Laboratory for Experimental Chemotherapy in Veterinary Parasitology of Federal Rural University of Rio de Janeiro (UFRRJ).

\subsection{Statistical analysis}

The calculation of $\mathrm{LC}_{50}$ (concentration that kill $50 \%$ of the treated population) was performed by probit analysis using Minitab ${ }^{\circledR}$ 16 (2013, Minitab Inc. LEADTOOLS, LEAD Technologies, Inc.). Statistical significance was set at $5 \%(p<0.05)$.

\section{Results and Discussion}

\subsection{Content and chemical characterization of the essential oil}

Ocimum gratissimum essential oil content obtained after hydrodistillation was $0.9 \%$ $(\mathrm{w} / \mathrm{w})$ and the analysis showed the phenylpropanoid eugenol (74.5\%) and the oxygenated monoterpene eucalyptol (14.8\%) as the major compounds (Table 1).

Ocimum gratissimum presents three important chemotypes (CT): CT eugenol, CT thymol and CT geraniol (Lima et al., 2018; Hue et al., 2015; Silva et al., 2015). ${ }^{25,26-19}$ In our work, we identified eugenol as the major compound $(74.5 \%)$, followed by eucalyptol (1,8-cineol). The relationship between $O$. gratissimum EOs chemical composition and their acaricidal efficacy against $R$. microplus was reported by Hue et al. (2015). ${ }^{26}$

\subsection{Larvicidal activity}

The bioassay results showed that 0 . gratissimum essential oil exhibited strong acaricidal activity against all tick larvae tested in the evaluated concentration range (Table 2 ). The best results were found against $R$. microplus and $A$. sculptum, with $100 \%$ efficacy at the concentration of $20 \mathrm{mg} \cdot \mathrm{mL}^{-1}$. The results were also good against $R$. sanguineus, with $100 \%$ and $96.53 \%$ efficacy at 40 and 20 $\mathrm{mg} \cdot \mathrm{mL}^{-1}$ respectively.

\section{3. $\mathrm{LC}_{50}$ establishment}

$\mathrm{LC}_{50}$ and slope values of $O$. gratissimum EO for all larvae of the three tick species are reported in the Table 3.

Larvicidal activity was more pronounced for $R$. microplus $\left(\mathrm{LC}_{50}=2.0 \mathrm{mg} \cdot \mathrm{mL}^{-1}\right)$, with relative potency up to 2.7 -fold higher than $A$. sculptum $\left(\mathrm{LC}_{50}=5.5 \mathrm{mg} \cdot \mathrm{mL}^{-1}\right)$ and 3.1-fold higher than $R$. sanguineus $\left(\mathrm{LC}_{50}=6.2 \mathrm{mg} \cdot \mathrm{mL}^{-1}\right)$. Our results corroborate the data reported by Monteiro et al. (2012) ${ }^{27}$, in which R. microplus larvae showed higher sensitivity to eugenol compared to Dermacentor nitens larvae. Previous studies have reported that $R$. microplus is more sensitive to the monoterpene thymol compared to $R$. sanguineus and $D$. nitens. ${ }^{28-30}$ These differences can be attributed to the variation in tick cuticle permeability and thickness. ${ }^{27}$

The control of $R$. microplus using $O$. gratissimum EO was reported by Hocayen et al. $(2013)^{31}$, but very high concentrations of EO were required to achieve mortality. Our results $\left(\mathrm{LC}_{50}=2.0 \mathrm{mg} \cdot \mathrm{mL}^{-1}\right)$ are 4.8 -fold higher than previously reported by Hue et al. $(2015)^{26}$, with $\mathrm{LC}_{50}$ of $9.8 \mathrm{mg} \cdot \mathrm{mL}^{-1}$ for $O$. gratissimum EO (CT eugenol) and 1.25 -fold higher than described by Lima et al. (2018) ${ }^{25}$,

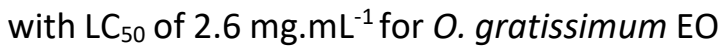
(CT thymol). 
Table 1. Essential oil chemical profile from Ocimum gratissimum obtained by hydrodistillation

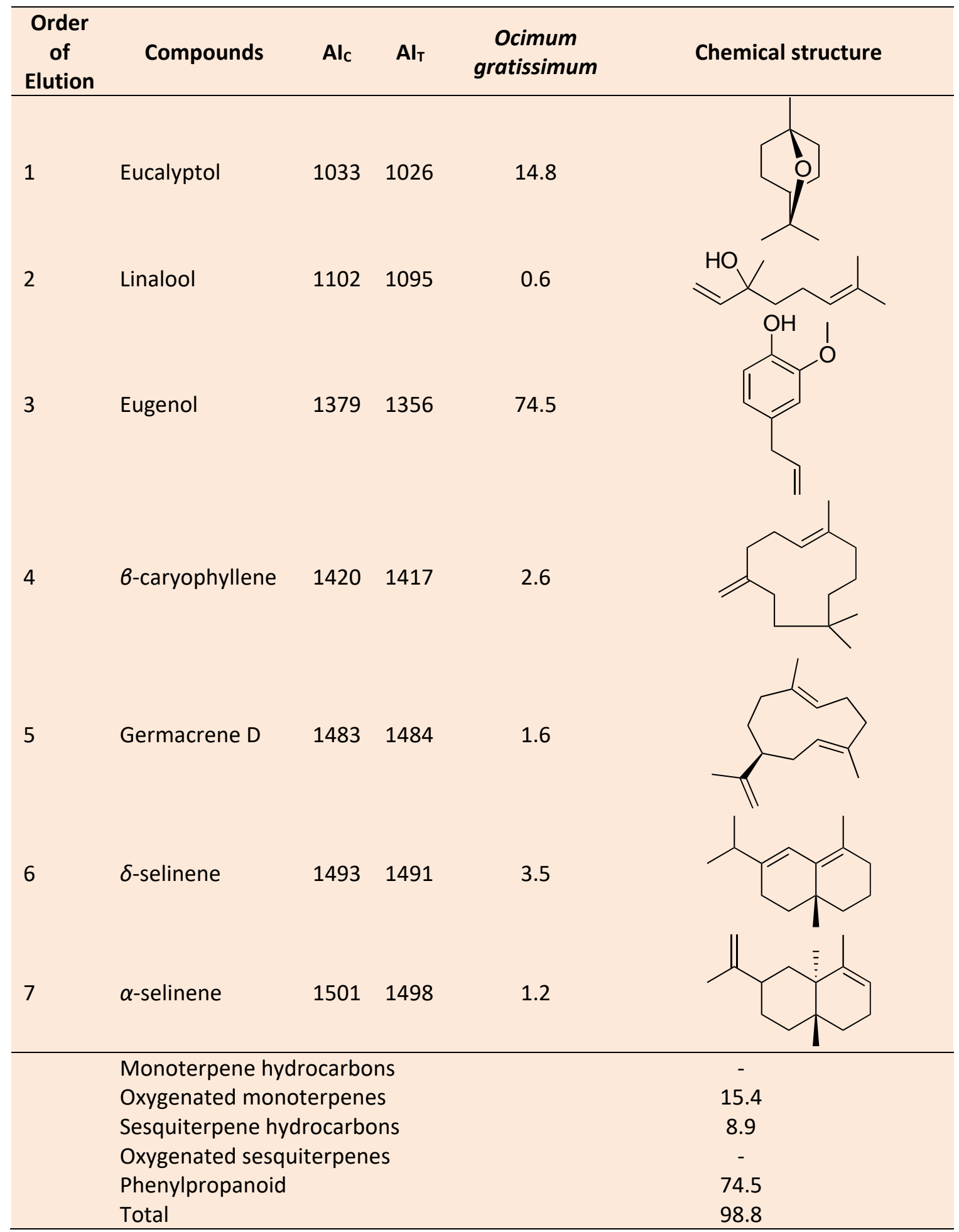

The chemical composition was analyzed by GC-MS and organized in the table by order of elution (EO) in the chromatographic column. The concentration (\%) was calculated based on the total area of the peak by GC-FID. Tabulated arithmetic index $\left(\mathrm{Al}_{\mathrm{T}}\right)$. Calculated arithmetic index $\left(A I_{c}\right)$ 
Ferreira, T. P. et al.

Table 2. In vitro larvicidal activity (\% mortality) of $O$. gratissimum essential oil against Amblyomma sculptum, Rhipicephalus microplus and Rhipicephalus sanguineus

\begin{tabular}{|c|c|c|c|}
\hline \multirow{2}{*}{$\begin{array}{l}\text { Essential oil } \\
\left(\mathrm{mg} \cdot \mathrm{mL}^{-1}\right)\end{array}$} & \multicolumn{3}{|c|}{ Tick species } \\
\hline & $\begin{array}{l}\text { Amblyomma } \\
\text { sculptum }\end{array}$ & $\begin{array}{l}\text { Rhipicephalus } \\
\text { microplus }\end{array}$ & $\begin{array}{c}\text { Rhipicephalus } \\
\text { sanguineus }\end{array}$ \\
\hline 40 & 100 & 100 & 100 \\
\hline 20 & 100 & 100 & 96.53 \\
\hline 10 & 68.18 & 93.10 & 91.11 \\
\hline 5 & 50.94 & 49.73 & 33.53 \\
\hline 2.5 & 32.64 & 25.15 & 2.78 \\
\hline 1.25 & 32.03 & 26.92 & 0 \\
\hline 0.625 & 13.28 & 12.84 & 0 \\
\hline 0.312 & 5.79 & 26.64 & 0 \\
\hline 0.156 & 0 & 28.02 & 0 \\
\hline 0.0781 & 0 & 12.99 & 0 \\
\hline Control (+) & 98.53 & 100 & 100 \\
\hline Control (-) & 0 & 0 & 0 \\
\hline
\end{tabular}

Table 3. $\mathrm{LC}_{50}\left(\mathrm{mg} \cdot \mathrm{mL}^{-1}\right.$ ) and slope of Ocimum gratissimum essential oil against larvae of Amblyomma sculptum, Rhipicephalus microplus and Rhipicephalus sanguineus

\begin{tabular}{lcc}
\hline \multicolumn{1}{c}{ Tick species } & LC $50\left(\mathrm{mg}^{\prime} \mathrm{mL}^{-1}\right)(\mathbf{9 5} \% \mathrm{Cl})$ & Slope (SE) \\
\hline Amblyomma sculptum & $5.533(4.054-8.742)$ & $3.909(0.258)$ \\
Rhipicephalus microplus & $2.042(1.572-2.605)$ & $1.280(0.103)$ \\
Rhipicephalus sanguineus & $6.253(5.704-6.827)$ & $4.841(0.399)$ \\
\hline
\end{tabular}

Probit analyses were performed for all data using Minitab ${ }^{\circledR} 16$ (2013, Minitab Inc., LEADTOOLS, LEAD Technologies, Inc.); LC 50 (mg. $\left.\mathrm{mL}^{-1}\right)(95 \% \mathrm{Cl}): 50 \%$ lethal concentration values together with their $95 \%$ confidence interval; Slope (SE): slope of the concentration curve and Standard Error 
Eugenol has already been reported in the literature as a natural inseticide ${ }^{33,26}$ and acaricide. ${ }^{33}$ The mortality ${ }^{30}$ and repellence ${ }^{34}$ activity against $R$. microplus of EOs containing eugenol as their major constituent have been described, mainly against $R$. microplus. ${ }^{25,} 26,31$, 34 However, activity against Dermacentor nitens $^{27}$ and $R$. appendiculatus ${ }^{35}$ has also been reported. Nevertheless, there is a lack of reports evaluating the acaricidal activity of Ocimum gratissimum EO as well as its major constituents' effects against $A$. sculptum and $R$. sanguineus.

The results obtained in the present work point to the potential use of Ocimum gratissimum essential oil for tick control. However, further research is needed, including the formulation of standardized veterinary products, to apply the active compounds efficiently and with a prolonged residual effect on the host's skin, as well as toxicology tests to evaluate possible effects on the host.

\section{Conclusion}

Ocimum gratissimum essential oil showed larvicidal efficacy in in vitro assays against larvae of Amblyomma sculptum, Rhipicephalus microplus and Rhipicephalus sanguineus. These findings, together with the chemical composition data, can support studies aiming at the development of products for the control of these ticks.

\section{Acknowledgements}

This study was supported by Fundação de Apoio à Pesquisa Tecnológica da Universidade Federal Rural do Rio de Janeiro (FAPUR), and part by the Coordenação de Aperfeiçoamento de Pessoal de Nível Superior - Brasil (CAPES) Finance Code 001 and Conselho Nacional de Desenvolvimento Científico e Tecnológico (CNPq).

\section{References}

${ }^{1}$ Bizzo, H. R.; Hovell, A. M. C.; Rezende, C. M. Brazilian essential oils: general view, developments and perspectives. Química Nova 2009, 32, 588. [CrossRef]

${ }^{2}$ Regnault-Roger, C.; Vincent, C.; Arnason, J. T. Essential Oils in Insect Control: Low-Risk Products in a High-Stakes World. Annual Review of Entomology 2012, 57, 405. [CrossRef]

${ }^{3}$ Adorjan, B.; Buchbaue, G. Biological properties of essential oils: an updated review. Flavour and Fragrance Journal 2010, 25, 407. [CrossRef]

${ }^{4}$ Chagas, A. C. S.; Oliveira, M. C. S.; Giglioti, R.; Santana, R. C. M.; Bizzo, H. R.; Gama, P. E.; Chaves, F. C. M. Efficacy of 11 Brazilian essential oils on lethality of the cattle tick Rhipicephalus (Boophilus) microplus. Ticks and Tick-borne Diseases 2016, 7, 427. [CrossRef]

${ }^{5}$ Ellse, L.; Wall, R. The use of essential oils in veterinary ectoparasite control: a review. Medical and Veterinary Entomology 2014, 28, 233. [CrossRef]

${ }^{6}$ Sanches, S. M.; Da Silva, C. H. T. D. P.; De Campos, S. X.; Vieira, E. M. Pesticidas e seus respectivos riscos associados à contaminação da água. Pesticidas: Revista de Ecotoxicologia e Meio Ambiente 2003, 13, 53. [CrossRef]

${ }^{7}$ Labruna, M. B.; Souza, S. L. P.; Guimarães, J. S.; Pacheco, R. C.; Pinter, A.; Gennari, S. M. Prevalência de carrapatos em cães de áreas rurais da região norte do Estado do Paraná Arquivo Brasileiro de Medicina Veterinária e Zootecnia 2001, 53, 553. [CrossRef]

${ }^{8}$ Aragão, H. de B. Ixodidas brasileiros e de alguns países limítrofes. Mem. Inst. Oswaldo Cruz 1936, 31, 759. [CrossRef]

${ }^{9}$ Sistema de Informação de Agravos de Notificação (SINAN). Disponível em: $<$ http://portalsinan.saúde.gov.br/febremacul osa>. Acesso em: 20 agosto 2019. 
10 Taylor, M. A.; Coop, R. L.; Wall, R. L.; Parasitologia Veterinária, 4a ed., Guanabara: Rio de Janeiro, 2017.

${ }^{11}$ Grisi, L.; Leite, R. C.; Martins, J. R. de S.; Barros, A. T. M. de; Andreotti, R.; Cançado, P. H. D.; León, A. A. P. de; Pereira, J. B.; Villela, H. S. Reassessment of the potential economic impact of cattle parasites in Brazil. Revista Brasileira de Parasitologia Veterinária 2014, 23, 150. [CrossRef] [PubMed]

12 Rodrigues, V. D. A. S.; Pina, F. T. B.; Barros, J. C.; Andreotti, R. Embrapa Gado de Corte. Comunicado Técnico, 2015, 10, 132. [Link]

${ }^{13}$ Guglielmone, A. A.; Beati, L.; BarrosBattesti, D. M.; Labruna, M. B.; Nava, S.; Venzal, J. M.; Mangold, A. J.; Szabó, M. P. J.; Martins, J. R.; González-Acuña, D.; EstradaPeña, A. Ticks (Ixodidae) on humans in South America. Experimental \& Applied Acarology 2006, 40, 83. [CrossRef] [PubMed]

${ }^{14}$ Smith, R. D.; Sells, D. M.; Stephenson, E. H.; Ristic, M. R.; Huxsoll, D. L. Development of Ehrlichia canis, causative agent of canine ehrlichiosis, in the tick Rhipicephalus sanguineus and its differentiation from a symbiotic Rickettsia. American Journal of Veterinaty Research 1976, 37, 119. [PubMed]

${ }^{15}$ Leite, R. C.; Oliveira, P. R.; Lopes, C. M. L.; Freitas, C. M. V.; Resumo do simpósio sobre Controle de Parasitos, Colina, Brasil, 1997.

${ }^{16}$ Alves, W. V.; Lorenzetti, E. R.; Gonçalves, F. C.; Utilização de acaricidas a base de plantas no controle de Rhipicephalus (Boophilus) microplus: uma contribuição para a produção e desenvolvimento sustentável. Revista Brasileira de Agropecuária Sustentável, 2012, 2,14 . [CrossRef]

17 Pandey, A. K.; Singh, P.; Tripathi, N. N. Chemistry and bioactivities of essential oils of some Ocimum species: an overview. Asian Pacific Journal of Tropical Biomedicine 2014, 4, 682. [CrossRef]

${ }^{18}$ Chowdhary, K.; Kumar, A.; Sharma, S.; Pathak, R.; Jangir, M. Ocimum sp.: Source of biorational pesticides. Industrial Crops and Products 2018, 122, 686. [CrossRef]
${ }^{19}$ Silva, M. K. N.; Carvalho, V. R. A.; Edinardo, M. F. F. Chemical profile of essential oil of Ocimum gratissimum L. and evaluation of antibacterial and drug resistance-modifying activity by gaseous contact method. Pharmacognosy Journal 2015, 8, 4. [CrossRef]

${ }^{20}$ Adams, R. P. Identification of essential oil components by gas chromatography-mass spectroscopy, Allured Pub Corp: Carol Stream, 1995.

${ }^{21}$ Van Den Dool, H.; Kratz, P. D. A generalization of the retention index system including linear temperature programmed gas-liquid partition chromatography. Journal of Chromatography $A$ 1963, 11, 463. [CrossRef] [PubMed]

${ }^{22}$ Shaw, R. D. Culture of an Organophosphorus-Resistant Strain of Boophilus microplus (Can.) and an Assessment of its Resistance Spectrum. Bulletin Entomological. Research 1966, 56, 389. [CrossRef] [PubMed]

${ }^{23}$ Leite, R. C.; Tese de Doutorado, Universidade Federal Rural do Rio de Janeiro, Brasil, 1988. [Link]

${ }^{24}$ Chagas, A. C. S.; Leite, R. C.; Furlong, J.; Prates, H. T.; Passos, W. M. Sensibilidade do carrapato Boophilus microplus a solventes. Ciência Rural 2002, 33, 109. [CrossRef]

${ }^{25}$ Lima, A. S; Milhomem, M. N.; Monteiro, O. S; Arruda, A. C. P.; de Castro, J. A. M.; Fernandes, Y. M. L.; Maia, J. G. S.; CostaJunior, L. M. Seasonal analysis and acaricidal activity of the thymol-type essential oil of Ocimum gratissimum and its major constituents against Rhipicephalus microplus (Acari: Ixodidae). Parasitology Research 2018, 117, 59. [CrossRef]

${ }^{26}$ Hüe, T.; Cauquil, L.; Fokou, J. B. H.; Dongmo, P. M. J.; Bakarnga-Via, I.; Menut, C. Acaricidal activity of five essential oils of Ocimum species on Rhipicephalus (Boophilus) microplus larvae. Parasitology Research 2015, 114, 91. [CrossRef]

27 De Monteiro, C. M.; Maturano, R.; Daemon, E.; Catunda, F. E. A.; Calmon, F.; De Souza Senra, T.; Faza, A.; De Carvalho, M. G. Acaricidal activity of eugenol on Rhipicephalus 
microplus (Acari: Ixodidae) and Dermacentor nitens (Acari: Ixodidae) larvae. Parasitology Research 2012, 111, 1295. [CrossRef] [PubMed]

${ }^{28}$ Novelino, A. M. S.; Daemon, E.; Soares, G. L. $G$. Evaluation of the acaricide effect of thymol, menthol, salicylic acid, and methyl salicylate on Boophilus microplus (Canestrini 1887) (Acari:Ixodidae) larvae. Parasitology Research 2007, 101, 809. [CrossRef] [PubMed]

${ }^{29}$ Daemon, E.; Ralph Maturano, R.; de Oliveira Monteiro, C. M.; Scoralik, M.; Massoni, T. Acaricidal activity of hydroethanolic formulations of thymol against Rhipicephalus sanguineus (Acari: Ixodidae) and Dermacentor nitens (Acari: Ixodidae) larvae. Veterinary Parasitology 2012, 186, 542. [CrossRef] [PubMed]

${ }^{30}$ Scoralik, M.; Daemon, E.; Monteiro, C. M. O.; Maturano, R. Enhancing the acaricide effect of thymol on larvae of the cattle tick Rhipicephalus microplus (Acari: Ixodidae) by solubilization in ethanol. Parasitology Research 2012, 110, 645. [CrossRef] [PubMed]

${ }^{31}$ Hocayen, P. A. S.; Pimenta, D. S. Extrato de plantas medicinais como carrapaticida de Rhipicephalus (Boophilus) microplus. Revista
Brasileira de Plantas Medicinais 2013, 15, 627. [CrossRef]

${ }^{32}$ Ajayi, O. E., Appel, G. A., Henry, Y. F. Fumigation toxicity of essential oil monoterpenes to Callosobruchus maculatus (Coleoptera: Chrysomelidae: Bruchinae). Journal of Insects 2014, 2014, 7 [CrossRef]

${ }^{33}$ Bissinger, B. W.; Roe, R. M. Tick repellents: past, present, and future. Pesticide Biochemistry and Physiology 2010, 96, 63. [CrossRef]

${ }^{34}$ Martinez-Velazquez, M.; Castillo-Herrera, G. A.; Rosario-Cruz, R.; Flores-Fernandez, J. M.; Lopez-Ramirez, J.; Hernandez-Gutierrez, R.; Lugo-Cervantes, E. D. C. Acaricidal effect and chemical composition of essential oils extracted from Cuminum cyminum, Pimenta dioica and Ocimum basilicum against the cattle tick Rhipicephalus (Boophilus) microplus (Acari: Ixodidae). Parasitology Research 2011, 108, 481. [CrossRef] [PubMed]

${ }^{35}$ Mwangi, E. N.; Hassanali, A.; Essuman, S.; Myandat, E.; Moreka, L.; Kimondo, M. Repellent and acaricidal properties of Ocimum suave against Rhipicephalus appendiculatus ticks. Experimental \& Applied Acarology 1995, 19, 11. [CrossRef] [PubMed] 